\title{
Grape and wine phenolics: Observations and recent findings
}

\author{
James A. Kennedy ${ }^{1}$ \\ Department of Food Science and Technology \\ Oregon State University, Corvallis, OR 97331, USA
}

\begin{abstract}
J.A. Kennedy. 2008. Grape and wine phenolics: Observations and recent findings. Cien. Inv. Agr. 35(2):107-120. What consumers taste in wine is the culmination of management practices from the vineyard to the glass. As researchers, in order to have control over the composition of wine at the time of consumption, it is important to understand how production practices affect wine chemistry. Because phenolic compounds are so important to the overall quality of wine, they are the subject of intense investigation throughout the world. This review is a summary of current knowledge and some recent findings that have taken place in this area.
\end{abstract}

Key words: Anthocyanins, proanthocyanidins, red wine, tannins, Vitis vinifera.

\section{Introduction}

Wine phenolics are important quality components that contribute to the color, taste, and feel of wines. Although phenolic compounds found in wine can also originate from microbial and oak sources, the majority of the phenolic constituents found in wine are grape-derived. In white wine, the most important phenolic compounds are the hydroxycinnamic acids and of minor quantities, the flavan-3-ol monomers. These compounds are important with regard to the visual quality of white wine.

In red wine, tannins and anthocyanins are the most important phenolic classes. Tannins contribute to the mouthfeel of wines but they also form pigmented polymers in association with the anthocyanins to provide the stable pigments required to give red wine its longterm color stability.

Winemakers inherently understand the importance of grape and wine phenolics to overall wine quality, yet increasingly, advances in grape and wine phenolic chemistry have

Received 16 October 2007. Accepted 21 April 2008.

${ }^{1}$ Corresponding author: james.kennedy@oregonstate.edu made it difficult to remain current in our understanding. The complex nature of many recent findings has also made it at times difficult to apply the science in way that can be used practically. This review is a summary of our current state of understanding in this area with an emphasis on recent findings.

\section{Grape phenolics}

Compoundsanddistribution. Themajorphenolic compounds from a wine quality perspective are the hydroxycinnamic acids, anthocyanins, and tannins (syn: proanthocyanidins or condensed tannins) (Ribéreau-Gayon, 1965-1963, 1959, Figures 1-3). The identification of these compounds has been accomplished and their distribution in the grape berry has been well documented (Figure 4).

Biosynthesis, accumulation and management. The biosynthesis of grape phenolics has been a subject of intense investigation recently (Bogs et al., 2007, 2005; Dixon et al., 2005; Xie et al., 2003; Winkel-Shirley, 2001; Boss et al., 1996). The biosynthesis of the phenolic compounds that are important to wine quality share a common pathway (Figure 5). While many of the genes in this pathway have been identified, portions of it remain speculative. In particular, 
<smiles>[R6]C(=O)/C=C/c1cc([R])c(O)c([R])c1</smiles>

\begin{tabular}{lll}
\hline Hydroxycinnamic Acid & $\mathrm{R}_{1}$ & $\mathrm{R}_{2}$ \\
\hline$p$-coumaric & $\mathrm{H}$ & $\mathrm{H}$ \\
caffeic & $\mathrm{OH}$ & $\mathrm{H}$ \\
ferulic & $\mathrm{OCH}_{3}$ & $\mathrm{H}$ \\
sinapic & $\mathrm{OCH}_{3}$ & $\mathrm{OCH}_{3}$ \\
\hline
\end{tabular}

$\underline{\mathrm{R}_{3} \text { esterification }}$<smiles>O=C(O)C(O)C(O)C(O)C(=O)O</smiles>

Figure 1. Hydroxycinnamic acids found in Vitis vinifera. proanthocyanidin production in plants is still incompletely understood (Dixon et al., 2005). Despite this, recent advances have been made with regard to the factors that are involved in gene regulation (Bogs et al., 2007).

The concentration of grape phenolics increases throughout berry development. Beginning at fruit set and when expressed on a weight basis, tannins and hydroxycinnamic acids increase until véraison (Downey et al., 2003; Kennedy et al., 2001, 2000; De Frietas et al., 2000; Romeyer et al., 1983). Beginning at véraison, anthocyanins accumulate in the berry and increase during fruit ripening. There is evidence that suggests that anthocyanins can decline late in berry development (Kennedy et al., 2002).

It is accepted that phenolic compounds are important to the quality of wine and therefore a considerable amount of research has been directed towards the understanding of how vineyard management practices influence their concentration in grapes.

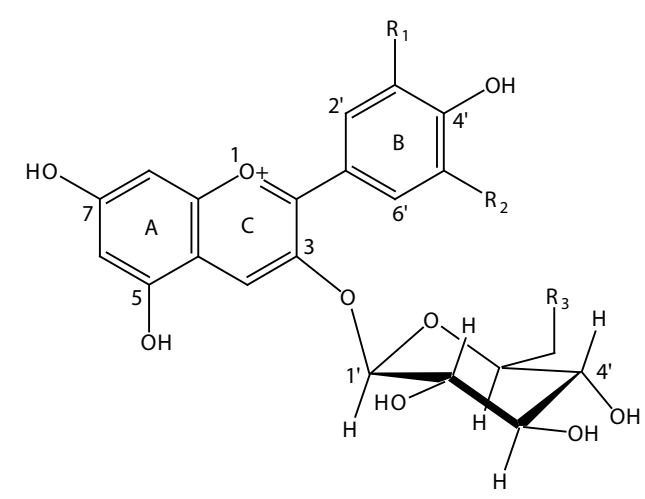

\begin{tabular}{lll}
\hline Anthocyanidin Moiety & $\mathrm{R}_{1}$ & $\mathrm{R}_{2}$ \\
\hline cyanidin & $\mathrm{OH}$ & $\mathrm{H}$ \\
peonidin & $\mathrm{OCH}_{3}$ & $\mathrm{H}$ \\
delphinidin & $\mathrm{OH}$ & $\mathrm{OH}$ \\
petunidin & $\mathrm{OCH}_{3}$ & $\mathrm{OH}$ \\
malvidin & $\mathrm{OCH}_{3}$ & $\mathrm{OCH}_{3}$ \\
\hline
\end{tabular}

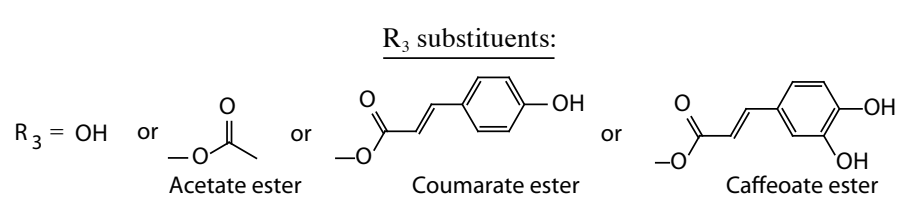

Figure 2. Anthocyanins found in Vitis vinifera. 


\begin{tabular}{|c|c|c|}
\hline Flavan-3-ol Monomer & $R_{1}$ & $\mathrm{R}_{2}$ \\
\hline (+)-catechin & $=\mathrm{OH}$ & $\mathrm{H}$ \\
\hline (-)-epicatechin & "mш". OH & $\mathrm{H}$ \\
\hline (-)-epigallocatechin & 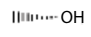 & $\mathrm{OH}$ \\
\hline (-)-epicatechin-3-0-gallate & & $\mathrm{H}$ \\
\hline
\end{tabular}

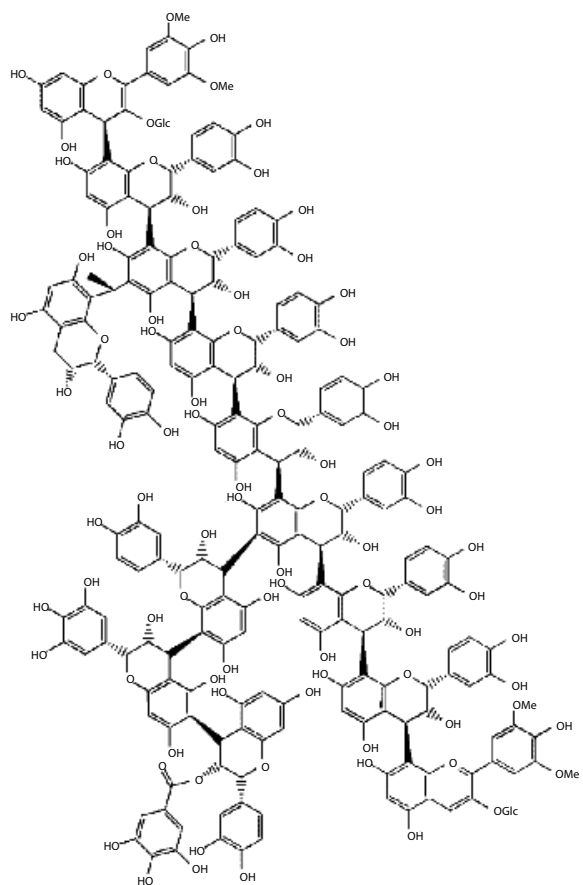

Figure 3. Flavan-3-ols found in grapes with an oligomer shown with various interflavonoid bonds as well as anthocyanin and ethylidene modifcations.

It is well established that phenolics vary with vintage (Cortell et al., 2007a, b; Pastor del Rio and Kennedy, 2006; Downey et al., 2003; Ribéreau-Gayon, 1972), and furthermore, that the cultural practice and environment around the developing fruit can effect composition (Pena-Neira et al., 2007; Smart et al., 1988). Fruit exposure influences phenolic production in the grape (Cortell and Kennedy, 2006; Downey et al., 2004; Bergqvist et al., 2001; Dokoozlian

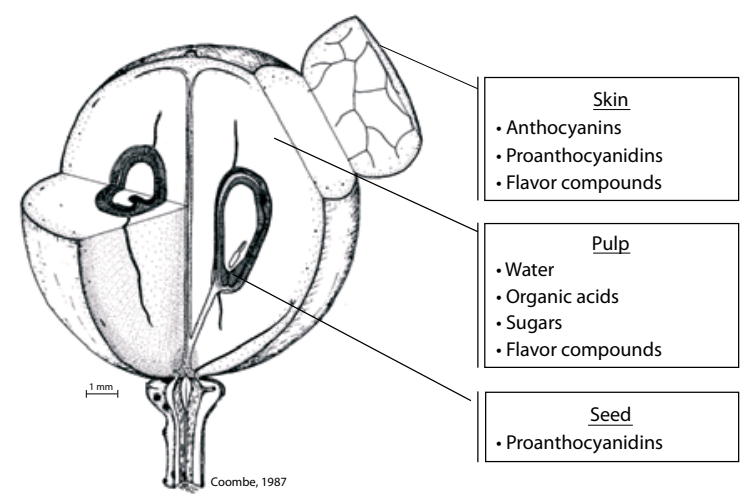

Figure 4. Distribution within the grape berry of compounds important to wine quality. 
and Kliewer, 1996; Price et al., 1995; Gao and Cahoon, 1994; Kliewer and Torres, 1972; Kliewer, 1977). Research recently by Spayd et $a l$. has shown that exposure differences can be due to temperature or light effects (Spayd et al., 2002). It is logical that the observed findings from commonly observed practices in vineyard management can be interpreted from changes in the exposure light/temperature environment around the fruit (Cortell et al., 2005; Kennedy et al., 2002, 2000; Ojeda et al., 2002; Mateus et al., 2001).

\section{Phenolic extraction during wine production}

Once grapes are harvested phenolic composition in the wine becomes dependent upon processing in the winery. With the exception of pulpderived hydroxycinnamic acids, phenolics derived from the skin and seed tissue makes up the vast majority of the phenolic pool present in wine, with stem-derived phenolics making a minor component if included. Determining the total quantity of phenolic compounds therefore is under winemaker control.

Because anthocyanins are localized in the skin tissue of most grape cultivars, fermentation and maceration have a profound effect on the amount of anthocyanin present in the final wine. An extreme example of this would be the separation of the solid parts of the grape berry from the juice with little or know maceration resulting in a wine with little or no red color. Sparkling wines made from cv. Pinot noir grapes are an example of how little color can be extracted.

Clearly, because of the localization of anthocyanins within plant cell vacuoles, diffusion needs to be considered. Diffusion is simply the process by which a compound moves from a region of high concentration toward a region of lower concentration (i.e.: from the plant cell into the wine). Considering the generally observed extraction curves for anthocyanins (Ribéreau-Gayon and Milhé, 1970; RibéreauGayon et al., 1970) and the effects that wine processing variables have on the rate of the compounds' extraction, the overall process is generally consistent with diffusion. Diffusion is dependent upon the following: 1 . Temperature,
2. Molecular weight/size and type of molecule, 3. Concentration gradient, 4. Cell permeability, 5. Surface area over the concentration gradient, and 6. Composition of extraction medium (such as ethanol concentration).

In all instances but molecular size, these variables contribute positively to the rate of diffusion. Time, of course, is an important variable for overall extraction.

Previous research has shown that in any given fermentation, time and temperature are the two critical variables in determining the ultimate amount of anthocyanin present in wine (Aron and Kennedy, 2007; Zimman et al., 2002; Kovac et al., 1992; Mayen et al., 1994; ScudamoreSmith et al., 1990; Aubert and Poux, 1969; Ough and Amerine, 1961; Berg and Akiyoshi, 1956). For anthocyanins, higher temperatures reduce the time to maximum concentration, and increase the maximal amount. Besides the most obvious variables of time and temperature, the other variables undoubtedly also play a role in anthocyanin extraction. Determining their relative importance, however, is difficult because of the compound nature of their affects.

With regard to tannins, and in addition to the diffusion variables described above, winemakers have a general preference with regard to the origin of the tannin: skin versus seed. It is generally thought that skin-derived tannins are "riper" than those found in the seed, and if a more developed wine is preferred, then skin tannins are desired. One explanation for the improvement in tannin quality with respect to fruit maturity is that there is an increase in the proportion of skin-derived tannins. Using a recently developed analytical method (Peyrot des Gachons, and Kennedy, 2003), Pastor del Rio and Kennedy (2006) found that wine made from increasingly mature grapes results in an increase in the proportion of seed-derived tannins. This observation is inconsistent with general wine industry explanation for tannin quality improvement.

Additional research does suggest however that an increase in the proportion of skin tannin (and amount) provides some explanation for wine tannin quality improvement (Cortell et 


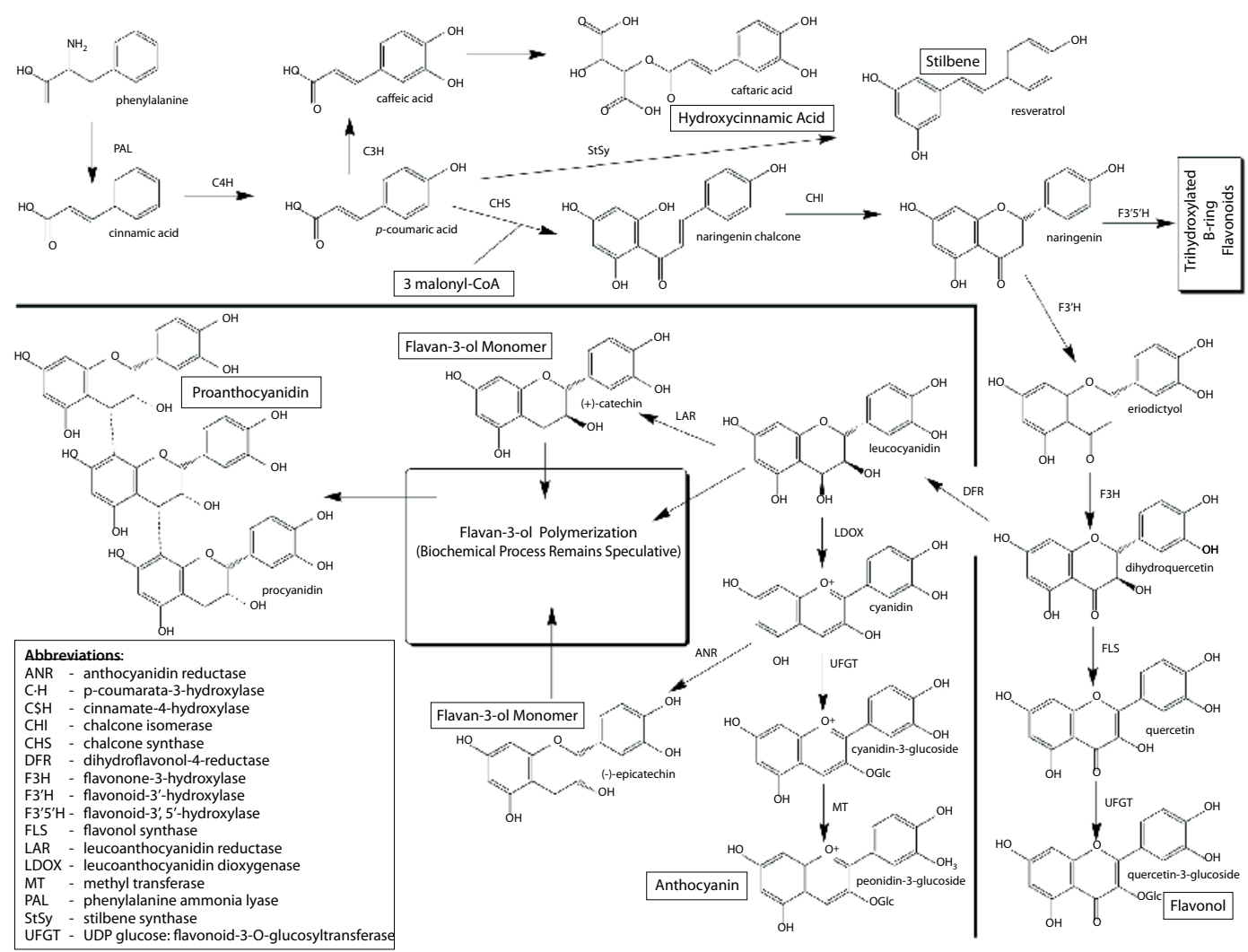

Figure 5. Phenylpropanoid biosynthetic pathway for the major phenolic classes found in wine.

al., 2005). Given this observation, and despite the evidence to date indicating that maturity does not increase skin tannin proportion, an improvement in tannin quality should be observed with an increase in the proportion of skin tannins found in wine. Skin tannins are generally extracted early in fermentation and as the maceration time increases, the rate at which seed tannin are extracted increases (Peyrot des Gachons and Kennedy, 2003). Tannin extraction will increase throughout fermentation (Ribéreau-Gayon et al., 1970) and therefore, at some point seed tannin dominates the tannins present in the wine. The trick from a winemaking perspective would be to optimize not only the quantity of tannin extracted, but also the proportion of skin and seed tannin.

In the final wine, the skin and seed tannin proportions are generally different than those found in the berry (Figure 6). In addition to grape maturity and maceration time, conditions in the vineyard (Cortell and Kennedy, 2006; Cortell et al., 2005) and the degree of berry crushing (unpublished data) have been found to influence the proportion of skin and seed tannin in wine. Understanding the consequence of tannin amount and composition from a perception standpoint is the long term key to understanding the best strategies for managing red wine quality both in the vineyard and in the winery.

The numbers indicated in this schematic (Figure 6) are based upon an actual experiment conducted on cv. Pinot Noir. Grape seed tannins exceed those found in the skin tissue and overall, a small portion of the overall quantity of tannins found in the grape is extracted during wine production. Finally, the maceration favored the extraction of skin tannins over seed tannins. 


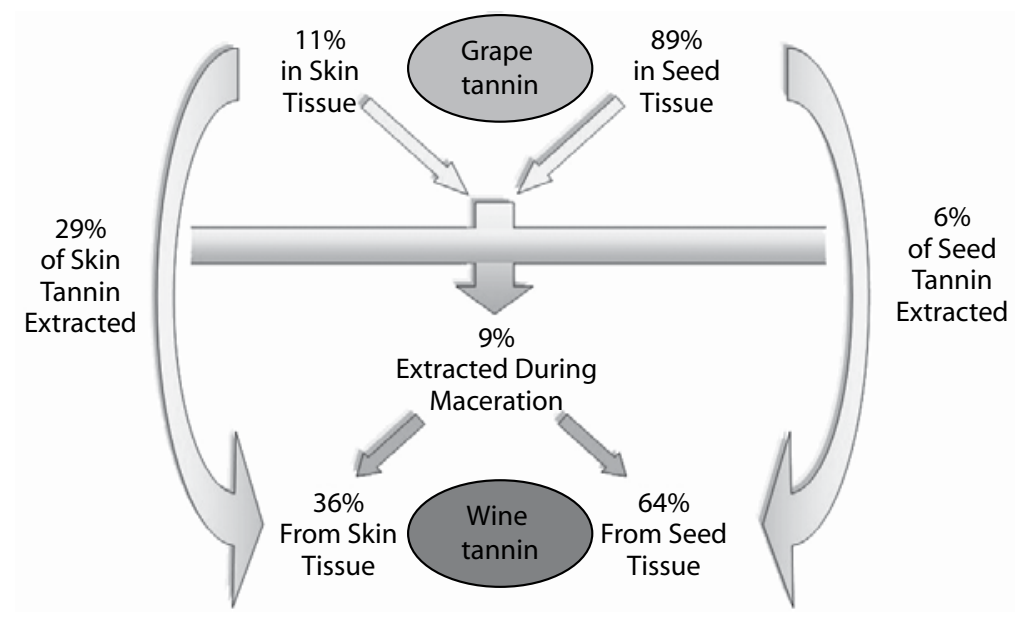

Figure 6. Schematic representation of skin and seed tannin extraction during maceration.

\section{Wine aging}

Once a wine is pressed, the concentration of grape phenolics is maximal, declining thereafter (Nagel and Wulf, 1979). In white wines, aging transforms lighter straw-colored wines into more deeply yellowed colors (Singleton and Kramling, 1976). In red wines, the initial bluered color anthocyanins are transformed into brick-red pigments. The overall depth of red wine color can be quite persistent despite there being very little grape-derived anthocyanin remaining. It is this aspect of red wine color that has fascinated wine scientists for well over a century.

It is generally recognized in red wines that grape-derived anthocyanins become modified with other compounds found in wine. One recently identified example of a modified anthocyanin combines the yeast metabolite pyruvic acid with anthocyanins to form vitisin A (Fulcrand et al., 1998; Bakker and Timberlake, 1997). Vitisin A forms early after fermentation has completed (Schwarz et al., 2003) and has the familiar brick-red color of an older wine as opposed to a new wine which is dominated by absorption at $520 \mathrm{~nm}$.

As wine ages, it is exposed to oxygen and the effects of oxidation (Waterhouse and
Laurie, 2006). A product of wine oxidation is ethanal, which is an oxidation product of ethanol oxidation (Wildenradt and Singleton, 1974). Evidence for ethanal incorporation into red wine phenolic polymers has been recently observed and increases with age as a proportion of the total phenolic polymer (Drinkine et al., $2007 \mathrm{a}, \mathrm{b})$. It has been observed for some time that ethanal formation leads to a modification of red wine color (Bakker and Timberlake, 1997; Timberlake and Bridle, 1976; Trillat, 1908a-c).

The formation of the vitisin pyranoanthocyanins in wine has subsequently led to the identification of other reactive nucleophiles including hydroxycinnamic acids and ethanal-flavan-3ol reaction products (He et al., 2006; Mateus et al., 2004, 2003; Benabdeljalil et al., 2000, Figure 7). In addition to ethanal mediated condensation reactions, recent work has shown that the oxidation of wine can result in the oxidation of glycerol to glyceraldehyde, another electrophilic species (Laurie and Waterhouse, 2006a, b).

The biggest challenge for wine scientists is characterizing the large molecular weight pigmented material present in red wine. Some time ago, structures were proposed for pigmented polymers and because of the prevalence of proanthocyanidins, these 

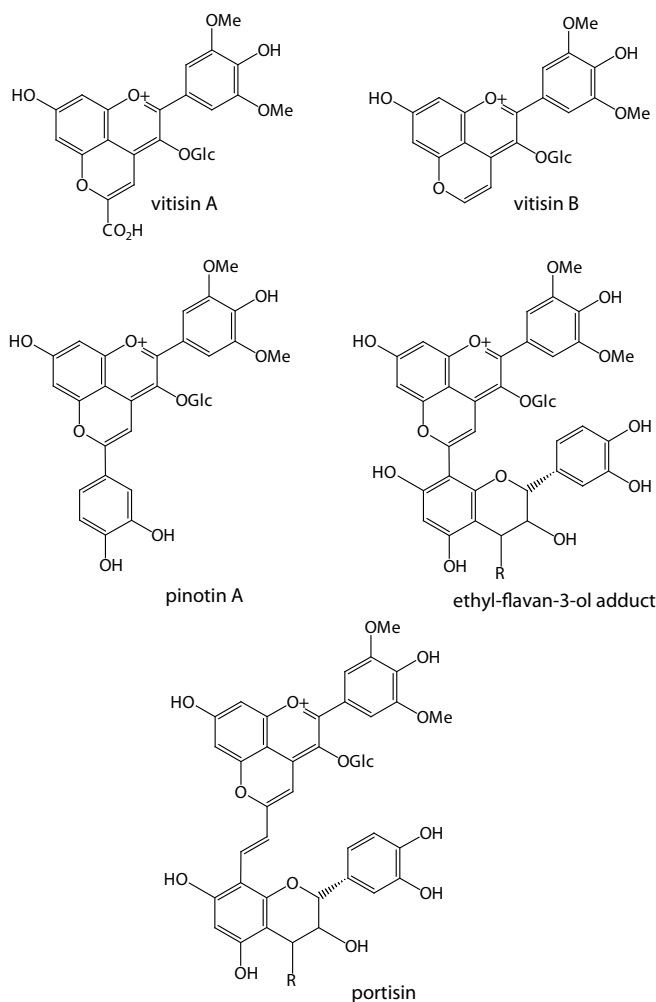

Figure 7. Examples of malvidin-3-O-glucoside-based pyranoanthocyanins that have been identified in red wine.

were speculated to involve anthocyanins and proanthocyanidins (Ribéreau-Gayon et al., 1983; Haslam, 1980; Somers, 1971; Jurd, 1969, $1967 \mathrm{a}, \mathrm{b})$. The accuracy of this speculation has been confirmed (Salas et al., 2004; VivarQuintana et al., 2002; Remy et al., 2000; EsSafi et al., 1999, Figure 8), and this chemistry has been extended into higher molecular weight material (Hayasaka and Kennedy, 2003). It is interesting to note that pigmented polymers begin formation early in a wine's life (Eglinton et al., 2004).

\section{Sensory properties of phenolics}

The complexity of phenolic perception is apparent when you realize that wine phenolics can be sensed by sight, smell, taste, and touch. Of these, grape phenolics are generally regarded as non-volatile and therefore they cannot be smelled. Anthocyanins and hydroxycinnamic acids as mentioned above provide the visual component in wines. Flavan-3-ol monomers are bitter and thus have taste. The tannins or proanthocyanidins are astringent, and because of this complex perception, some discussion of this follows.

Tannins are compounds that seem to be designed by nature to be deterrents to herbivores and fungi. Tannins accomplish this because of their ability to bind strongly to proteins (Haslam, 1998). Brought back to wine, it is generally considered that we observe this as a loss of lubrication due to the tannins binding and precipitating our salivary proteins. To put it simply, tannins are astringent, terribly astringent (Gawel, 1998; Noble, 1994). Astringency is a tactile sensation and therefore, we feel it. This gives rise to the common term used to describe tannins in wine: mouthfeel.

Beyond astringency, tannins can also possess bitterness, which is a taste sensation and is brought about by the lowest molecular weight tannins (Kallithraka et al., 1997; Robichaud and Noble, 1990; Arnold et al., 1980). It is generally considered that too much bitterness in wine is not desirable and based upon the reduction in the lowest molecular weight tannins observed during berry maturation, this may provide a structural explanation for why tannin quality improves with fruit maturity.

Considering tannin perception in total, the astringency of tannins has a distinct temporal aspect to their perception (Ishikawa and Noble, 1995). When wines have and excess quantity of tannins, the astringency of the wine can linger beyond that of other components. This persistence is generally thought of as being undesirable.

Although bitterness and astringency is found in red wines, it is not a descriptor that is often used in a production setting. Instead, winemakers tend to describe tannins in terms that provide subquality information. Sensory scientists and chemists have spent a considerable amount of time trying to understand these more subtle aspects of tannin perception (Fernández et al., 2007; Lesschaeve and Noble, 2005; Vidal et al., 2004a, 2003; Gawel et al., 2001, 2000; Cheynier et al., 1998). 
<smiles>COc1cc(-c2cc(OC)c3c(O)cc(O)c(C4c5c(O)cc(O)c(C6c7c(O)cc(O)cc7OC(c7ccc(O)c(O)c7)C6O)c5OC(c5ccc(O)c(O)c5)C4O)c3c2)cc(OC)c1O</smiles>

T-A type Trimer<smiles>COc1cc(C23Oc4cc(O)cc(O)c4C2(COc2c(O)cc(O)c4c2OC(c2ccc(O)c(O)c2)C(O)C4c2c(O)cc(O)c4c2OC(c2ccc(O)c(O)c2)C(O)C4)Oc2c(O)cc(O)cc23)cc(OC)c1O</smiles>

Bicyclic form<smiles>COC1=C(c2cc(OC)c(O)c(OC)c2)Oc2cc(O)cc(O)c2C1c1c(O)cc(O)c2c1OC(c1ccc(O)c(O)c1)C(O)C2c1c(O)cc(O)c2c1OC(c1ccc(O)c(O)c1)C(O)C2</smiles>

A-T type Trimer

Ethyl-bridged Trimer

Figure 8. Examples of malvidin-3-O-glucoside proanthocyanidin derivatives.

From these investigations, it is clear that the perception of astringency in wine could be influenced by many components in wine including ethanol (Fischer and Noble, 1994), acidity (Peleg et al., 1998; Fischer and Noble, 1994), viscosity (Smith et al., 1996), simple sugars (Boselli et al., 2004), polysaccharides (Vidal et al., 2004b; Riou et al., 2001) and anthocyanins (Vidal et al., 2004b). Increasingly there are tools being developed in the winery that have an impact on tannin perception (Del Carmen-Llaudy et al., 2006). It is difficult to convey how difficult these studies are to conduct because of the variation in human response to astringency and bitterness (Fischer et al., 1994). Moreover, the complex interaction between tannins and other macromolecules found in wine (De Freitas et al., 2003; Riou et al., 2001; Saucier et al., 1997a, b) indicates that fully understanding the nature of tannin perception will continue to be a challenging area of research.

Perhaps a good way of conceptualizing tannin perception and the relationship between tannin description and grape composition is to think about how different grape components influence our perception of tannins (Figure 9). Here tannins and acid are balanced with ethanol sugar and polysaccharides. As a winemaker, the goal is to balance these components in a red wine. Initially, when picked early, a wine would have a tendency to have excess tannins and acidity with a deficiency in polysaccharides, sugar and 
ethanol. As the fruit becomes more mature, the composition becomes more balanced and the descriptors become more positive. A winemaker has the ability to modulate wine descriptors by adjusting the balance accordingly. The figure as depicted is in line with research on tannins and perception.

From the research gathered to date, including the biosynthesis of tannins and the overall development of the berry, the picture that is emerging is that tannin changes in the grape do occur and their relative amounts in the skin and seed vary depending on grape production practice. Moreover, the changes that occur during berry maturation (Kennedy, 2002) that do not involve tannins are expected to result in changes that positively influence the quality of tannins.

The continued progress in grape and wine phenolic researchin many ways willdepend on the continuing development of analytical chemistry. The recent progress in our understanding can very much be related to analytical advances. Additional progress in analytical chemistry has been made recently and it is exciting to see that attention is being directed towards making analytical information easy to acquire and rapid (Fernández and Agosin, 2007; Mercurio et al., 2007; Cozzolino et al., 2006). These advances will likely lead to an improvement in grape and wine phenolic management.

\section{Resumen}

Lo que los consumidores prueban en el vino es la culminación de prácticas de manejo que parten en el viñedo y concluyen en la copa. Como investigadores, para tener un control sobre la composición del vino al momento del consumo, es importante comprender como afectan las prácticas de manejo la composición química del vino. Debido a que los compuestos fenólicos tienen tal importancia sobre la calidad final del vino, estos compuestos han sido objeto de una intensa investigación mundial. Esta revisión de literatura es un resumen del conocimiento actual y de algunos descubrimientos recientes que han ocurrido en esta área.

Palabras clave: Antocianinas, protoantocianidinas, taninos, vinos tintos, Vitis vinifera.

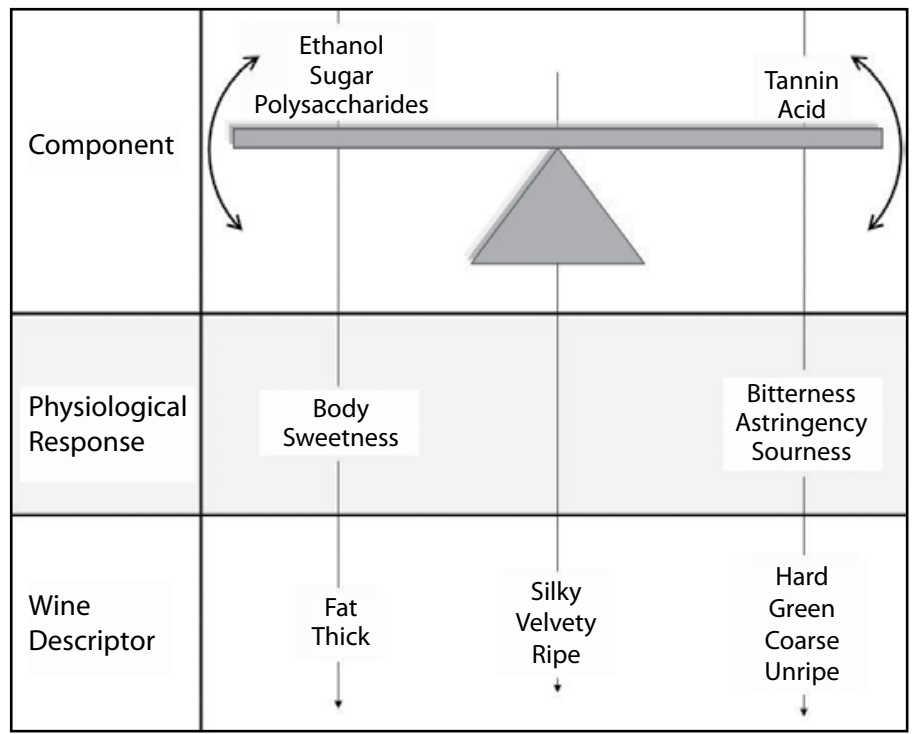

Figure 9. Schematic representation for the description of tannins based upon wine composition 


\section{References}

Arnold, R.A., A.C. Noble, and V.L. Singleton. 1980. Bitterness and astringency of phenolic fractions in wine. J. Agric. Food Chem. 28:675-678.

Aron, P.M., and J.A. Kennedy. 2007. Compositional investigation of phenolic polymers isolated from Vitis vinifera L. cv. Pinot noir during fermentation. J. Agric. Food Chem. 55:56705680.

Aubert, S., and C. Poux. 1969. Extraction des composés phénoliques du raison II. Taux de passage dans les vins. Ann. Technol. Agric. 18:111-127.

Bakker, J., and C.F. Timberlake. 1997. Isolation, identification, and characterization of new color stable anthocyanins occurring in some red wines. J. Agric. Food Chem. 45:35-43.

Benabdeljalil, C., V. Cheynier, H. Fulcrand, A. Hakiki, M. Mosaddak, and M. Moutounet. 2000. Evidence of new pigments resulting from reaction between anthocyanins and yeast metabolites. Sciences des Aliments 20:203-220.

Berg, H.W., and M. Akiyoshi. 1956. The effect of contact time of juice with pomace on the color and tannin content of red wines. Am. J. Enol. Vitic. 7:84-90.

Bergqvist, J., N. Dokoozlian, and N. Ebisuda. 2001. Sunlight exposure and temperature effects on berry growth and composition of Cabernet Sauvignon and Grenache in the central San Joaquin Valley of California. Am. J. Enol. Vitic. 52:1-7.

Bogs, J., M.O. Downey, J.S. Harvey, A.R. Ashton, G.J. Tanner, and S.P. Robinson. 2005. Proanthocyanidin synthesis and expression of genes encoding leucoanthocyanidin reductase and anthocyanidin reductase in developing grape berries and grapevine leaves. Plant Physiol. 139:652-663.

Bogs, J., F.W. Jaffé, A.M. Takos, A.R. Walker, and S.P. Robinson. 2007. The grapevine transcription factor VvMYBPA1 regulates proanthocyanidin synthesis during fruit development. Plant Physiol. 143:1347-1361.

Boss, P.K., C. Davies, and S.P. Robinson. 1996. Analysis of the expression of anthocyanin pathway genes in developing Vitis vinifera $\mathrm{L}$. cv. Shiraz grape berries and the implications for pathway regulation. Plant Physiol. 111:10591066.

Boselli, E., R.B. Boulton, J.H. Thorngate, and N.G. Frega. 2004. Chemical and sensory characterization of DOC red wines from Marxhe (Italy) related to vintage and grape cultivars. J. Agric. Food Chem. 52:3843-3854.

Cheynier, V., H. Fulcrand, F. Brossaud, C. Asselin, and M. Moutounet. 1998. Phenolic composition as related to red wine flavor. Pages 125-141. In: Chemistry of Wine Flavor. A.L. Waterhouse and S.E. Ebeler (eds.). Oxford University Publishing, NY. USA.

Cortell, J.M., M. Halbleib, A.V. Gallagher, T. Righetti, and J.A. Kennedy. 2005. Influence of vine vigor on grape (Vitis vinifera L. cv. Pinot noir) and wine proanthocyanidins. J. Agric. Food Chem. 53:5798-5808.

Cortell, J.M., and J.A. Kennedy. 2006. Effect of shading on accumulation of flavonoid compounds in Vitis vinifera L. Pinot noir fruit and extraction in a model system. J. Agric. Food Chem. 54:8510-8520.

Cortell, J.M., M. Halbleib, A.V. Gallagher, T. Righetti, and J.A. Kennedy. 2007a. Influence of vine vigor on grape (Vitis vinifera L. cv. Pinot noir) anthocyanins. 1. anthocyanin concentration and composition in fruit. J. Agric. Food Chem. 55:6575-6584.

Cortell, J.M., M. Halbleib, A.V. Gallagher, T. Righetti, and J.A. Kennedy. 2007b. Influence of vine vigor on grape (Vitis vinifera $\mathrm{L}$. Cv. Pinot noir) anthocyanins. 2. anthocyanins and pigmented polymers in wine. J. Agric. Food Chem. 55:6585-6595.

Cozzolino, D., R.G. Dambergs, L. Janik, W.U. Cynkar, and M. Gishen. 2006. Analysis of grapes and wine by near infrared spectroscopy. J. Near Infrared Spectr. 14:279-289.

De Frietas, V.A.P., Y. Glories, and A. Monique. 2000. Developmental changes of procyanidins in grapes of red Vitis vinifera varieties and their composition in respective wines. Am. J. Enol. Vitic. 51:397-403.

De Freitas, V., E. Carvalho, and N. Mateus. 2003. Study of carbohydrate influence on proteintannin aggregation by nephelometry. Food Chemistry 81:503-509.

Del Carmen-Llaudy, M.R., S. Canals, J.M. GonzálezManzano, C. Canals, C. Santos-Bulega, and F. Zamora. 2006. Influence of micro-oxygenation treatment before oak aging on phenolic compounds composition, astringency, and color of red wine. J. Agric. Food Chem. 54:4246-4252.

Dixon, R.A., D.Y. Xie, and S.B. Sharma. 2005. Proanthocyanidins - a final frontier in flavonoid research? New Phytol. 165:9-28.

Dokoozlian, N.K., and W.M. Kliewer. 1996. Influence of light on grape berry growth and composition varies during fruit development. J. Am. Soc. Hort. Sci. 121:869-874.

Downey, M.O., J.S. Harvey, and S.P. Robinson. 2003. Analysis of tannins in seeds and skins of Shiraz grapes throughout berry development. Aust. J. Grape Wine Res. 9:15-27. 
Downey, M.O., J.S. Harvey, and S.P. Robinson. 2004. The effect of bunch shading on berry development and flavonoid accumulation in Shiraz grapes. Aust. J. Grape Wine Res. 10:5573.

Drinkine, J., P. Lopes, J.A. Kennedy, P.-L. Teissedre, and C. Saucier. 2007a. Analysis of ethylidenebridged flavan-3-ols in wine. J. Agric. Food Chem. 55:1109-1116.

Drinkine, J., P. Lopes, J.A. Kennedy, P.-L. Teissedre, and C. Saucier. 2007b. Ethylidene-bridged tannins in red wine and correlation with wine age. J. Agric. Food Chem. 55:6292-6299.

Eglinton, J., M. Griesser, P. Henschke, M. Kwiatkowski, M. Parker, and M. Herderich. 2004. Yeast mediated formation of pigmented polymers in red wine. Pages 125-142. In: Red Wine Color: Revealing the Mysteries. A.L. Waterhouse, J. Kennedy (eds.). ACS Symposium series 886, American Chemical Society. Washington, DC, USA.

Es-Safi, N., H. Fulcrand, V. Cheynier, and M. Moutounet. 1999. Studies on the acetaldehydeinduced condensation of (-)-epicatechin and malvidin 3-O-glucoside in a model solution system. J. Agric. Food Chem. 47:2096-2102.

Fernández, K., J.A. Kennedy, and E. Agosin. 2007. Characterization of grape and wine proanthocyanidins of Vitis vinifera cv. Carmenere. J. Agric. Food Chem. 55:36753680 .

Fernández, K., and E. Agosin. 2007. Quantitative analysis of red wine tannins using fouriertransform mid-infrared spectrometry. J. Agric. Food Chem. 55:7294-7300.

Fischer, U., R.B. Boulton, and A.C. Noble. 1994. Physiological factors contributing to the variability of sensory assessments: relationship between salivary flow rate and temporal perception of gustatory stimuli. Food Qual. Pref. 5: 55-64.

Fischer, U., and A.C. Noble. 1994. The effect of ethanol, catechin concentration and $\mathrm{pH}$ on sourness and bitterness of wine. Am. J. Enol. Vitic. 45:6-10.

Fulcrand, H., C. Benabdeljalil, J. Rigaud, V. Cheynier, V., and M. Moutounet. 1998. A new class of wine pigments generated by reaction between pyruvic acid and grape anthocyanins. Phytochemistry 47:1401-1407.

Gao, Y., and G.A. Cahoon. 1994. Cluster shading effects on fruit quality, fruit skin color, and anthocyanin content and composition in Reliance (Vitis hybrid). Vitis 33:205-209.

Gawel, R. 1998. Red wine astringency: a review. Aust. J. Grape Wine Res. 4:74-95.

Gawel, R., A. Oberholster, and I.L. Francis.
2000. A mouth-feel wheel: Terminology for communicating the mouth-feel characteristics of red wine. Aust. J. GrapeWine Res. 6:203-207.

Gawel, R., P.G. Iland, and I.L. Francis. 2001. Characterizing the astringency of red wine: a case study. Food Qual. Pref. 12:83-94.

Haslam, E. 1980. In vino veritas: oligomeric procyanidins and the ageing of red wines. Phytochemistry 19:2577-2582.

Haslam, E. 1998. Taste, bitterness and astringency. Pages 178-225. In: E. Haslam (ed.). Practical Polyphenolics: From Structure to Molecular Recognition and Physiological Action. Cambridge: Cambridge University Press. UK.

He, J., C. Santos Buelga, N. Mateus, and V.A.P. de Freitas. 2006. Isolation and quantification of oligomeric pyranoanthocyanin-flavanol pigments from red wines by combination of column chromatographic techniques. J. Chromatogr. A 1134:215-225.

Hayasaka, Y., and J.A. Kennedy. 2003. Mass spectrometric evidence for the formation of pigmented polymers in red wine. Aust. J. Grape Wine Res. 9:210-220.

Ishikawa, T., and A.C. Noble. 1995. Temporal perception of astringency and sweetness in red wine. Food Qual. Pref. 6:27-33.

Jurd, L. 1967a. Anthocyanidins and related compounds-XI. Catechin-flavylium salt condensation reactions. Tetrahedron 23:10571064.

Jurd, L. 1967b. Catechin-flavylium salt condesation reactions. Tetrahedron 23:1057-1064.

Jurd, L. 1969. Review of polyphenol condensation reactions and their possible occurrence in the aging of wines. Am. J. Enol. Vitic. 20:191-195.

Kallithraka, S., J. Bakker, and M.N. Clifford. 1997. Evaluation of bitterness and astringency of (+)catechin and (-)-epicatechin in red wine and in model solution. J. Sensory Stud. 12:25-37.

Kennedy, J.A., M.A. Matthews, and A.L. Waterhouse. 2000. Changes in grape seed polyphenols during ripening. Phytochemistry 55:77-85.

Kennedy, J.A., Y. Hayasaka, S. Vidal, E.J. Waters, and G.P. Jones. 2001. Composition of grape skin proanthocyanidins at different stages of berry development. J Agric. Food Chem. 49:5348-5355.

Kennedy, J.A., M.A. Matthews, and A.L. Waterhouse. 2002. Effect of maturity and vine water status on grape skin and wine flavonoids. Am. J. Enol. Vitic. 53:268-274.

Kennedy, J.A. 2002. Understanding berry development. Practical Winery and Vineyard July/August. p. 14-23.

Kliewer, W.M., and R.E. Torres. 1972. Effect of controlled day and night temperatures on grape 
coloration. Am. J. Enol. Vitic. 23:71-77.

Kliewer, W.M. 1977. Influence of temperature, solar radiation and nitrogen on coloration and composition of Emperor grapes. Am. J. Enol. Vitic. 28:96-103.

Kovac, V., E. Alonso, M. Bourzeix, and E. Revilla. 1992. Effect of several enological practices on the content of catechins and proanthocyanidins of red wines. J. Agric. Food Chem. 40:19531957.

Laurie, V.F., and A.L. Waterhouse. 2006a. Glyceraldehyde bridging between flavanols and malvidin-3-glucoside in model solutions. J. Agric. Food Chem. 54:9105-9111.

Laurie, V.F., and A.L. Waterhouse. 2006b. Oxidation of glycerol in the presence of hydrogen peroxide and iron in model solutions and wine. Potential effects on wine color. J. Agric. Food Chem. 54:4668-4673.

Lesschaeve, I., and A.C. Noble. 2005. Polyphenols: factors influencing their sensory properties and their effects on food and beverage preferences. Am. J. Clin. Nutr. 81:330s-335s.

Mateus, N., S. Marques, A.C. Gonçalves, J.M. Machado, and V. de Freitas. 2001. Proanthocyanidin composition of red Vitis vinifera varieties from the Duoro valley during ripening: Influence of cultivation altitude. Am. J. Enol. Vitic. 52:115-121.

Mateus, N., E. Carvalho, R.F.A. Carvalho, A. Melo, M.A. Gonzales-Paramas, C. Santos-Buelga, and V. A.P. de Freitas. 2003. Isolation and structural characterization of new acylated anthocyaninvinyl-flavanol occurring in aging red wines. J. Agric. Food Chem. 51:277-282.

Mateus, N., J. Oliveira, C. Santos-Buelga, A.M.S. Silva, and V.A.P. de Freitas. 2004 NMR structure characterization of a new vinylpyranoanthocyanin-catechin pigment (a portisin). Tetrahedron Lett. 45:3455-3457.

Mayen, M., J. Merida, and M. Medina. 1994. Free anthocyanins and polymeric pigments during the fermentation and post-fermentation standing of musts from Cabernet Sauvignon and Tempranillo grapes. Am J. Enol. Vitic. 45:161-166.

Mercurio, M.D., R.G. Dambergs, M.J. Herderich, and P.A. Smith. 2007. High throughput analysis of red wine and grape phenolics - adaptation and validation of methyl cellulose precipitable tannin assay and modified Somers color assay to a rapid 96 well plate format. J. Agric. Food Chem. 55:4651-4657.

Nagel, C.W., and L.W. Wulf. 1979. Changes in the anthocyanins, flavonoids and hydroxycinnamic acid esters during fermentation and aging of Merlot and Cabernet Sauvignon. Am. J. Enol.
Vitic. 30:111-116.

Noble, A.C. 1994. Bitterness in wine. Physiol. Behav. 6:1251-1255.

Ojeda, H., C. Andary, E. Kraeva, A. Carbonneau, and A. Deloire. 2002. Influence of pre- and postveraison water deficit on synthesis and concentration of skin phenolic compounds during berry growth of Vitis vinifera cv. Shiraz. Am. J. Enol. Vitic. 53:261-267.

Ough, C.S., and M.A. Amerine. 1961. Studies on controlled fermentation V. Effects on color, composition and quality of red wine. Am. J. Enol. Vitic. 12:9-19.

Pastor del Rio, J., and J.A. Kennedy. 2006. Development of proanthocyanidins in Vitis vinifera $\mathrm{L}$. cv. Pinot noir grapes and extraction into wine. Am. J. Enol. Vitic. 57:125-131.

Peleg, H., K.K. Bodine, and A.C. Noble. 1998. The influence of acid on astringency of alum and phenolic compounds. Chem. Senses 23:371378.

Pena-Neira, A., A. Caceres, C. Pastenes. 2007. Low molecular weight phenolic and anthocyanin composition of grape skins from cv. Syrah (Vitis vinifera L.) in the Maipo Valley (Chile): Effect of clusters thinning and vineyard yield. Food Sci. Technol. Int. 13:153-158.

Peyrot des Gachons, C., and J.A. Kennedy. 2003. Direct method for determining seed and skin proanthocyanidin extraction in red wine. J. Agric. Food Chem. 51:5877-5881.

Price, S.F., P.J. Breen, M. Valladao, and B.T. Watson. 1995. Cluster exposure and quercetin in Pinot noir grapes and wine. Am. J. Enol. Vitic. 46:187-194.

Remy, S., H. Fulcrand, B. Labarbe, V. Cheynier, and M. Moutounet. 2000. First confirmation in red wine of products resulting from direct anthocyanin-tannin reactions. J. Sci. Food Agric. 80:745-751

Ribéreau-Gayon, P. 1959. Recherches sur les anthocyannes des végétaux. Application au genre Vitis.Librairie General del'Enseignement. Paris, France.

Ribéreau-Gayon, P. 1963. Les acides-phénols de Vitis vinifera. Compt. Rend. 256:4108-4111.

Ribéreau-Gayon, P. 1964. Les composés phénoliques $\mathrm{du}$ raisin et du vin.II. Les flavonosides et les anthocyanosides. Ann. Physiol. Vég. 6:211-242.

Ribéreau-Gayon, P. 1965. Identification d'esters des acides des acides cinnamiques et l'acide tartrique dans les limbes et les baies de Vitis vinifera. Compt. Rend. 260:341-343.

Ribéreau-Gayon, P. 1968. Les Composés Phénololiques des Végétaux. Dunod, Paris, France. p. 264

Ribéreau-Gayon, P., P. Sudraud, J.C. Milhé, and 
A. Canbas. 1970. Reserches technologiques sur les composes phenoliques des vin rouges II. Les factors de dissolution des composes phénoliques. Conn. Vigne Vin 4:133-144.

Ribéreau-Gayon, P., and J.C. Milhé. 1970. Reserches technologiques sur les composes phenoliques des vin rouges I. Influence des differentes parties de la grappe. Conn. Vigne Vin 4:63-74.

Ribéreau-Gayon, P. 1972. Évolution des composés phénoliques au cours de la maturation du raisin. II. Discussion des résultats obtenus en 1969, 1970, et 1971. Conn. Vigne Vin 6:161-175.

Ribéreau-Gayon, P., P. Pontallier, and Y. Glories. 1983. Some interpretations of colour changes in young red wines during their conservation. J. Sci. Food Agric. 34:505-516.

Riou, V., A. Vernhet, T. Doco, and M. Moutounet. 2001. Aggregation of grape seed tannins in model wine-effect of wine polysaccharides. Food Hydrocolloids 16:17-23.

Robichaud, J.L., and A.C. Noble. 1990. Astringency and bitterness of selected phenolics in wine. J. Sci. Food Agric. 53:343-353.

Romeyer, F.M., J.J. Macheix, J.P. Goiffon, C.C. Reminiac, and J.C. Sapis. 1983. The browning capacity of grapes. 3. Changes and importance of hydroxycinnamic acid-tartaric acid esters during development and maturation of the fruit. J. Agric. Food Chem. 31:346-349.

Salas, E., C. Le Guernevé, H. Fulcrand, C. PoncetLegrand, and V. Cheynier. 2004. Structure determination and color properties of a newly synthesized direct-linked flavanol-anthocyanin dimer. Tetrahedron Lett. 45: 8725-8729.

Saucier, C., C. Guerra, M. Laguerre, and Y. Glories. 1997a. (+)-catechin-acetaldehyde condensation products in relation with wine-ageing. Phytochemistry 46:229-234.

Saucier, C., G. Bourgeois, C. Vitry, D. Roux, and Y. Glories. 1997b. Characterization of (+)catechin-acetaldehyde polymers: a model for colloidal state of wine polyphenols. J. Agric. Food Chem. 45:1045-1049.

Schwarz, M., P. Quast, D. von Baer, and P. Winterhalter. 2003. Vitisin A content in Chilean wines from Vitis vinifera cv. Cabernet Sauvignon and contribution to the color of aged red wines. J. Agric. Food Chem. 51:6261-6267.

Scudamore-Smith, P.D., R.L. Hooper, and E.D. McLaran. 1990. Color and phenolic changes of Cabernet Sauvignon wine made by simultaneous yeast/bacterial fermentation and extended pomace contact. Am. J. Enol. Vitic. 41:57-67.

Singleton, V.L., and T.E. Kramling. 1976. Browning of white wines and an accelerated test for browning capacity. Am. J. Enol. Vitic. 27:157-160.

Smart, R.E., S.M. Smith, and R.V. Winchester.
1988. Light quality and quantity effects on fruit ripening for Cabernet Sauvignon. Am. J. Enol. Vitic. 39:250-258.

Smith, A.K., H. June, and A.C. Noble. 1996. Effects of viscosity on the bitterness and astringency of grape seed tannin. Food Qual. Pref. 7:161-166.

Somers, T.C. 1971. The polymeric nature of wine pigments. Phytochemistry 10:2175-2186.

Spayd, S.E., J.M. Tarara, D.L. Mee, and J.C. Ferguson. 2002. Separation of sunlight and temperature effects on the composition of Vitis vinifera cv. Merlot berries. Am. J. Enol. Vitic. 53:171-182.

Timberlake, C.F., and P. Bridle. 1976. Interactions between anthocyanins, phenolic compounds and acetaldehyde and their significance in red wines. Am. J. Enol. Vitic. 27:97-105.

Trillat, A. 1908a. L'aldehyde acétique dans le vin, son origine et ses effets. Ann. De l'Institut Pasteur 22:704-719.

Trillat, A. 1908b. L'aldehyde acétique dans le vin, son origine et ses effets. Ann. De l'Institut Pasteur 22:753-762.

Trillat, A. 1908c. L'aldehyde acétique dans le vin, son origine et ses effets. Ann. De l'Institut Pasteur 22:876-895.

Vidal, S., P. Courcoux, L. Francis, M. Kwiatkowski, R. Gawel, P. Williams, E. Waters, and V. Cheynier. 2004a. Use of an experimental design approach for evaluation of key wine components on mouth-feel perception. Food Qual. Pref. 15:209-217.

Vidal, S., P. Courcoux, L. Francis, P. Williams, M. Kwiatkowski, R. Gawel, V. Cheynier, and E. Waters. 2004b. The mouth-feel properties of polysaccharides and anthocyanins in a wine like medium. Food Chem. 85:519-525.

Vidal, S., L. Francis, S. Guyot, N. Marnet, M. Kwiatkowski, R. Gawel, V. Cheynier, and E. J. Waters. 2003. The mouth-feel properties of grape and apple proanthocyanidins in a winelike medium. J. Sci. Food Agric. 83:564-573.

Vivar-Quintana, A.M., C. Santos-Buelga, and J.C. Rivas-Gonzalo. 2002. Anthocyanin-derived pigments and colour of red wines. Anal. Chim. Acta 458:147-155.

Waterhouse, A.L., and V.F. Laurie. 2006. Oxidation of wine phenolics: A critical evaluation and hypothesis. Am. J. Enol. Vitic. 57:306-313.

Wildenradt, H.L., and V.L. Singleton. 1974. The production of aldehydes as a result of oxidation of polyphenolic compounds and its relation to wine aging. Am. J. Enol. Vitic. 25:119-126.

Winkel-Shirley, B. 2001. It takes a Garden. How work on diverse plant species has contributed to an understanding of flavonoid metabolism. Plant Physiol. 127:1399-1404. 
Xie, D.Y., S.B. Sharma, N.L. Paiva, D. Ferreira, and R.A. Dixon. 2003. Role of anthocyanidin reductase, encoded by BANYULS in plant flavonoid biosynthesis. Science 299:396-399.
Zimman, A., W.S. Joslin, M.L. Lyon, J. Meier, and A.L. Waterhouse. 2002. Maceration variables affecting phenolic composition in commercialscale Cabernet Sauvignon winemaking trials. Am. J. Enol. Vitic. 53:93-98. 